\title{
RELIABILITY ANALYSIS AND BREACH MODELLING OF SEA/ ESTUARY DIKES AND COASTAL DUNES IN AN INTEGRATED RISK ANALYSIS
}

\author{
Marie Naulin ${ }^{1}$, Andreas Kortenhaus ${ }^{1}$ and Hocine Oumeraci ${ }^{1}$
}

In order to quantify the risk of flooding, an integrated risk analysis is being performed within the German 'XtremRisK' project (Extreme storm surges at open coasts and estuarine areas: risk assessment and mitigation under climate change aspects) wherein one task is to analyze the reliability and breaching of flood defences. In this paper, the methods and results of the reliability analysis and the breach modelling of sea and estuary dikes and coastal dunes are discussed and applied to examples of the pilot sites of Hamburg (Elbe Estuary) and the Island of Sylt (North Sea). These results are put in context of an integrated flood risk analysis approach used in XtremRisK.

Keywords: reliability analysis, failure mechanisms, sea dike, dune, flood defences, risk analysis, breaching

\section{INTRODUCTION}

Catastrophic damages due to storm surges along coasts may be caused by the total failure, i.e. breaching, of coastal flood defences. In the past, storm surges have led to failures of these defences which caused major damages and loss of life also along the European North Sea Coast. For example, the North Sea flood of 1953 caused over 2,500 fatalities in The Netherlands and the United Kingdom and the North Sea flood of 1962 caused over 300 fatalities in Germany. In the coming decades, it may be expected that the risk of flooding will increase due to climate change (IPCC 2007). Furthermore, the uncertainties associated to climate change and the resulting impacts on storm surge and sea waves are very high. Hence, reliability-based methods, explicitly taking into account these uncertainties, are suitable tools to analyse the performance of flood defence elements subject to extreme storm surges.

In order to quantify the flood risk from extreme storm surges, methods for an integrated risk analysis are developed within the German 'XtremRisK' project (Extreme storm surges at open coasts and estuarine areas: risk assessment and mitigation under climate change aspects, www.xtremrisk.de) running from 2008 to 2012. The approach is based on the source-pathway-receptor concept (Figure 1; Oumeraci, 2004). In this project, flood risk is defined as the product of probability of flooding and related consequences. Hence, one task is to determine the probability of the hinterland being flooded. Moreover, in case of structural failure of sea dikes or coastal dunes the breaching of these defences is analysed in order to describe the initial conditions for a flood wave inundating the hinterland.

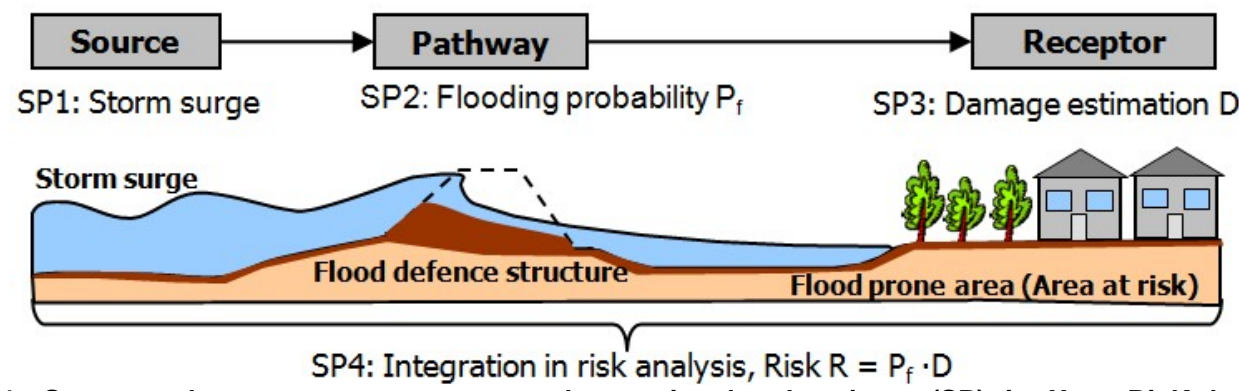

Figure. 1. Source-pathway-receptor concept and associated subprojects (SP) in XtremRisK based on Oumeraci (2004).

This paper summarises the key findings of the "risk pathway" analysis of XtremRisK Subproject 2 (SP 2), the main tasks of which comprise a reliability analysis and a breach modelling of coastal and estuarine flood defences. A detailed description of the applied methodology has been discussed in Naulin et al. 2010, 2011. In this paper, the focus is set on the key results and the progress in reliability analysis and breach modelling of flood defences. The methods were applied to pilot sites in Hamburg (Elbe Estuary) and the Island of Sylt (North Sea). The results were used for an integrative risk analysis to illustrate how they contribute to proposing risk mitigation measures.

First, after a short introduction of the project and the pilot sites, the extreme storm surge scenarios which were developed within the risk sources analyses in Subproject 1 (SP 1, Gönnert et al. 2012; Wahl et al. 2012) are briefly described as these scenarios serve as input data for the risk pathway analyses.

\footnotetext{
${ }^{1}$ Leichtweiß-Institute for Hydraulic Engineering and Water Resources, Department of Hydromechanics and Coastal Engineering, Technische Universität Braunschweig, Beethovenstraße 51a, 38108 Braunschweig, Germany; m.naulin@tu-bs.de
} 
Afterwards, the methods and results of the analysis of the flood defence lines are discussed in order to perform segmentations into sections and in order to determine up to 80 characteristic input parameters per type of flood defence element.

Following, the methods and results of the reliability analysis will be introduced. The reliability analysis is performed for different "homogeneous" sections of the flood defence lines. The failure probability is calculated using a fault tree approach combining about 35 failure modes for the main linear flood defence elements, i.e. dikes, coastal dunes and flood defence walls. The resulting flooding probabilities are used in Subproject 4 (SP 4) for risk analysis (Burzel et al., 2012; Dassanayake et al., 2012).

Thereafter, the methods and results of the calculations of combined wave overtopping and overflow and modelling of sea dike breaching are outlined in this paper. This comprises three steps: (a) the calculation of combined wave overtopping and overflow discharges along the whole flood defence line; (b) identification of weak sections based on the results of the reliability analysis (with high probability of failure); and (c) analysis of breach initiation and breach development using different breach models. The results of the initial condition of the flood wave (breach outflow hydrograph, breach width etc.) are used in Subproject 3 (SP 3) for inundation modelling of the hinterland and damage estimation (Ujeyl et al., 2012).

Furthermore, as one example of a gap in knowledge the importance of time-dependent aspects in reliability analyses is outlined. Using the example of the limit state equations 'wave overtopping' and 'overflow' it is shown how to consider the unsteady state of water levels and wave parameters instead of just looking at the peak values of storm surge parameters.

Finally, the methods and results will be briefly summarized and main conclusions will be drawn.

\section{Risk Pathways Analysis in XtremRisK Project}

As mentioned before, methods for the integrated event-based risk analysis have been developed in 'XtremRisK' (Oumeraci et al. 2012). The source-pathway-receptor concept (Figure 1) used here comprises storm surge analyses (risk sources), calculation of failure probabilities of flood defences including breach modelling of dikes and dunes (risk pathways), the quantification of potential losses in the hinterland (risk receptors), and its integration into an overall risk analysis.

The "risk pathways", i.e. the way the risk travels from its source via flood defences to the receptors, is analysed within SP 2 of XtremRisK. The flow chart of the pathway analysis in the integrated risk analysis framework is shown in Figure 2.

\section{Study Sites}

The pilot sites, Hamburg and Sylt, are located in the northern part of Germany (Figure 3a). As an example for an open coast, the Island of Sylt in the North Sea is analysed whereas the Elbe Estuary of the city of Hamburg serves as an example for an estuarine urban area. However, the methods developed in XtremRisK are generic enough to be applied to other coastal and estuarine areas at risk.

Since a complete risk analysis of the total area of Hamburg and Sylt Island would exceed the work capacity in the framework of XtremRisK, typical subareas with characteristic properties were chosen. In Hamburg the subareas of Wilhelmsburg, Polder Hamburg Süd, and a part of the city centre were selected for the detailed study (Figure 3b). For Sylt Island the subareas of Hörnum and Westerland were selected for the detailed study (Figure 3c), for a detailed description of the pilot sites see Naulin et al. (2010).

In Hamburg there is a strong influence of the water level by the tidal dynamics of the North Sea with a mean high tide of $2.1 \mathrm{~m}$ above Normal Null (NN, datum for water level in Germany). The current design water level is $7.30 \mathrm{~m} \mathrm{NN}$ at the tide gauge of St. Pauli, Hamburg. Estuary dikes, flood defence walls and a huge number of "point structures" to close the openings in the harbour area in case of a storm surge are found as main flood defence elements in Hamburg.

At Sylt, the mean high tide is about $1.0 \mathrm{~m} \mathrm{NN}$ and the current design water level is $4.50 \mathrm{~m} \mathrm{NN}$.

Since wind and wave attack are predominantly originating from westerly directions, there is a severe wave loading on the west side of the island. As natural flood defence elements coastal dunes can mainly be found on the west side of the island. Moreover, especially in Westerland, concrete revetments and sea walls have been built. The east side of the island is protected by sea dikes, flood walls and revetments. 


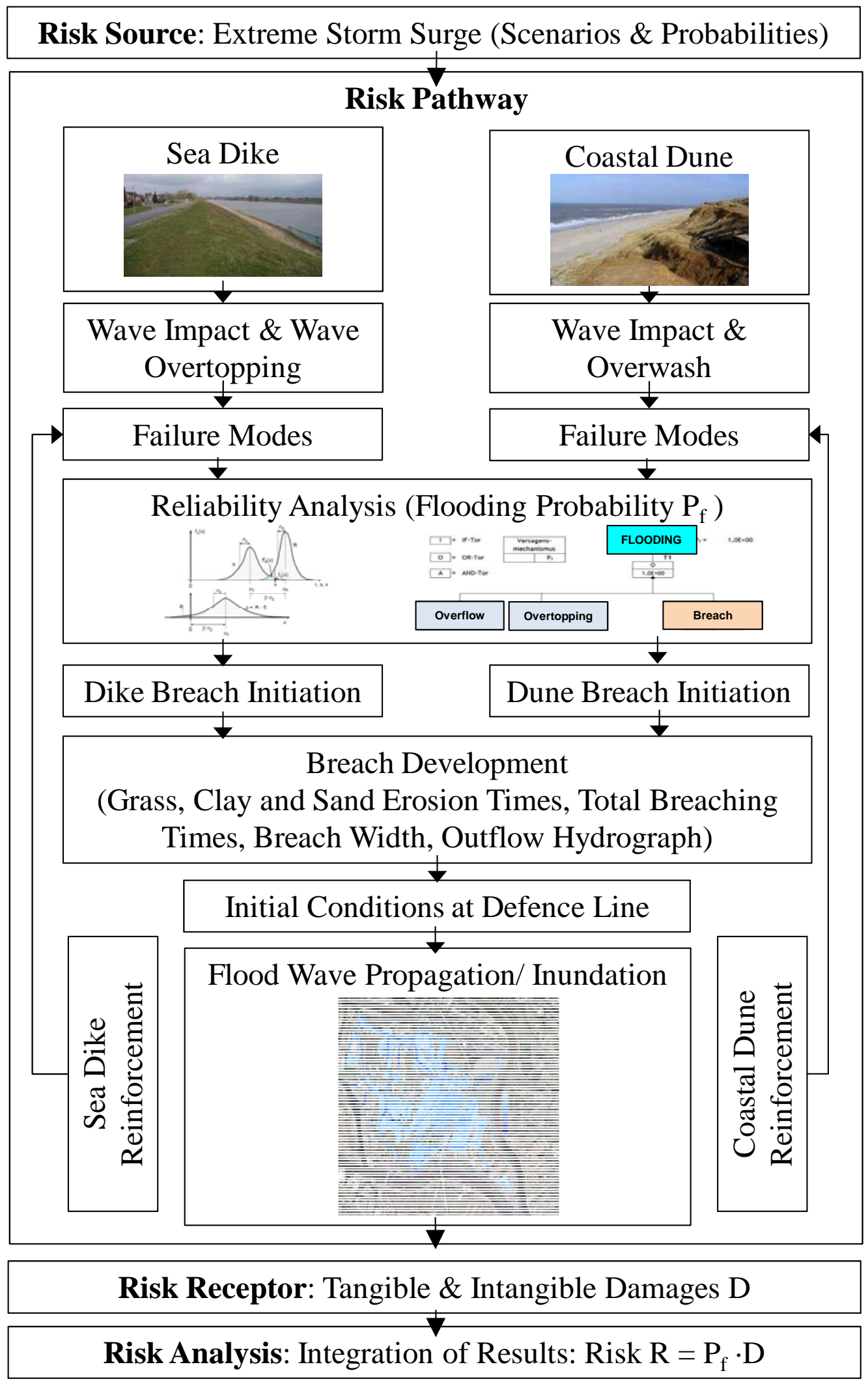

Figure 2. Flow chart of risk pathways analysis in an integrated risk analysis framework. 

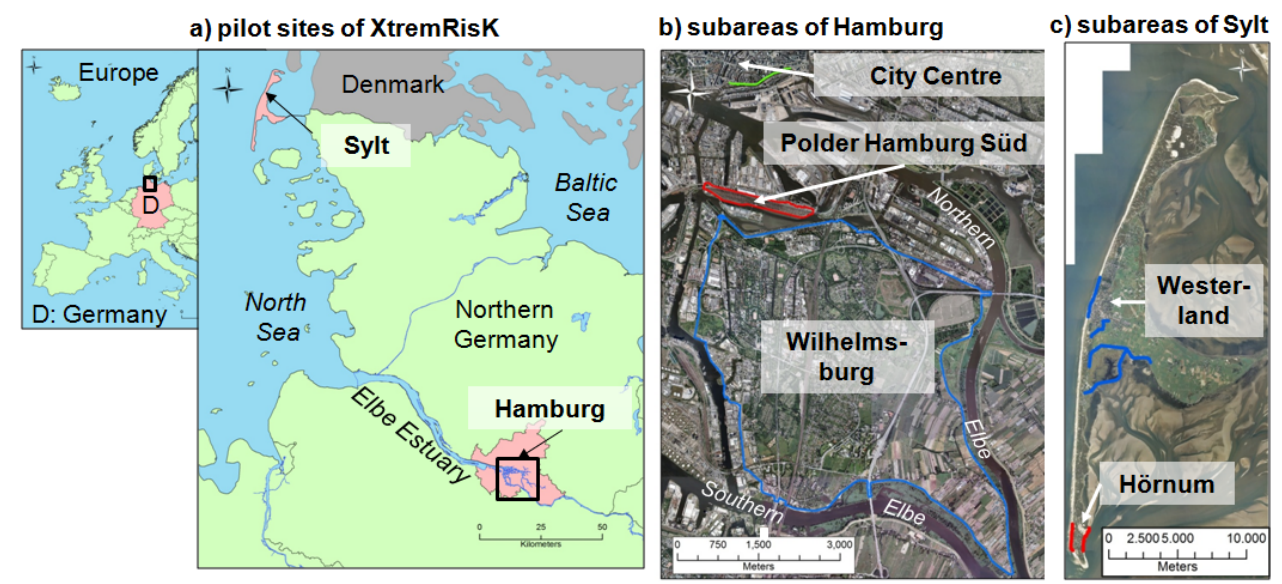

Figure 3. Study sites in XtremRisK a) location; b) Hamburg; c) Sylt (modified after Naulin et al., 2010/2011).

\section{EXTREME STORM SURGE SCENARIOS}

In SP 1, different extreme storm surge scenarios under current and future climate change conditions were determined (see Gönnert et al. 2012; Wahl et al. 2012). An overview of the developed storm surge scenarios for current climate change conditions (“year 2010”) with their peak water levels and exceedance probabilities is given in Table 1. As it can be seen very extreme scenarios with very high water levels and low exceedance probabilities were investigated. For future climate change scenarios ("year 2100") relative mean sea level rises of $40 \mathrm{~cm}$ and $80 \mathrm{~cm}$ were considered for all scenarios, e.g. HH-XR2100A40 and HH-XR2100A80. The exceedance probabilities $\mathrm{P}_{\mathrm{e}}$ were determined based on multivariate statistics (Wahl et al. 2012), eg. bivariate (peak water level and fullness, i.e. intensity of the storm surge curve) or trivariate (the aforementioned parameters plus discharge or waves). Hence, the failure probabilities of the flood defence system $\mathrm{P}_{\mathrm{f}}$ will be determined as conditional probabilities $\mathrm{P}_{\mathrm{f}, \mathrm{cond}}$, depending on the selected water level scenarios.

Table 1. Storm surge scenarios developed by SP 1 (Gönnert et al. 2012; Wahl et al. 2012) exemplarily for the tide gauge St. Pauli, Hamburg, and Hörnum, Sylt.

\begin{tabular}{|c|c|c|c|}
\hline & storm surge scenario & $\begin{array}{c}\text { peak water level } \\
{[\mathrm{m} \mathrm{NN}]}\end{array}$ & $\begin{array}{c}\text { exceedance probability } \\
\text { (HH: trivarate/ SY: bivariate) [1/year] }\end{array}$ \\
\hline \multirow{4}{*}{ 息 } & HH-XR2010A & 8.00 & $7.72 \cdot 10^{-6}$ \\
\hline & HH-XR2010A-90 & 7.10 & $2.36 \cdot 10^{-3}$ \\
\hline & HH-XR2010B & 7.25 & $8.09 \cdot 10^{-8}$ \\
\hline & HH-XR2010C & 8.64 & $5.30 \cdot 10^{-8}$ \\
\hline \multirow{4}{*}{ 齐 } & SY-XR2010A & 5.13 & $5.38 \cdot 10^{-6}$ \\
\hline & SY-XR2010A-90 & 4.19 & $7.85 \cdot 10^{-3}$ \\
\hline & SY-XR2010B & 4.50 & $7.09 \cdot 10^{-5}$ \\
\hline & SY-XR2010C & 4.89 & $3.06 \cdot 10^{-4}$ \\
\hline
\end{tabular}

Furthermore, wave modelling using the model SWAN (simulating waves nearshore, Holthuijsen et al. 1989) was performed leading to results of simulated wave heights at the toe of the defences $\mathrm{H}_{\mathrm{S}}$ up to $0.8 \mathrm{~m}$ with peak periods of up to $\mathrm{T}_{\mathrm{p}}=2.6 \mathrm{~s}$ for Hamburg and $\mathrm{H}_{\mathrm{S}}=2.5 \mathrm{~m}$ and $\mathrm{T}_{\mathrm{p}}=8.6 \mathrm{~s}$ for the west side of Sylt Island.

For the east side of Sylt Island due to a lack of data in the bathymetry and wave observation and a less importance of wave loading at the lee zone of the island the wave parameters were estimated based on expert's judgements to $H_{S}=0.8 \mathrm{~m}$ and $T_{p}=4.0 \mathrm{~s}$ (Wahl et al. 2012).

\section{ANALYSIS OF FLOOD DEFENCE LINES}

\section{Methods}

Input parameters describing the characteristics of the flood defences were required in order to perform reliability analysis and breach modelling. For the selected characteristic subareas of the pilot sites, an overview and a detailed parameterisation of all flood defence structures were performed based on an intensive analysis of inventory data such as measurements of the coastal defences as well as geotechnical surveys and digital elevation models. The data collection was carried out in collaboration with the local flood defence authorities of the pilot sites.

Using this data basis, which was managed in a geographical information system (GIS), the flood defence line of each subarea was then divided into homogeneous sections with similar characteristics 
such as type of structure, geometric and geotechnical parameters. Moreover, the hydraulic conditions such as water level and wave conditions were also considered for the subdivision.

The identified segments are assumed to be homogenous and independent. Hence, a simplification is made and length effects, i.e. increase of the probability of failure with the increasing length of a section, are currently not taken into account.

For these sections, all input parameters and their uncertainties were investigated based on the results of the intensive data collection and analysis. Depending on the type of flood defence element, dikes, dunes and flood defence walls were parameterised by over 80, 40, and 50 parameters, respectively. In case of a lack of data - especially in the case of geotechnical parameters - the data and their uncertainties were estimated by literature references such as Kortenhaus (2003).

\section{Results}

An overview of the results focusing on dikes and coastal dunes of the analysis of the flood defence line of the different subareas of the pilot sites in Hamburg and Sylt is given in Table 2. For each subarea of the pilot sites, the flood defence type, the number and length of the identified sections and their crown heights were analysed.

For example the subarea of Hamburg Wilhelmsburg is protected by a flood defence line with a length of $23.8 \mathrm{~km}$ which were divided into 94 sections, including 71 dike sections.

The investigated subareas of Sylt Island include $6.5 \mathrm{~km}$ of flood defences divided into 48 sections in Hörnum and 20.2 km divided into 89 sections in Westerland.

Table 2. Results of the segmentation of dikes and coastal dunes as flood defence elements for the different subareas of the pilot sites Hamburg and Sylt.

\begin{tabular}{|c|c|c|c|c|c|c|}
\hline \multirow{2}{*}{\multicolumn{2}{|c|}{ subarea }} & \multirow{2}{*}{ type of flood defence } & \multirow{2}{*}{$\begin{array}{c}\text { number } \\
{[-]}\end{array}$} & \multirow{2}{*}{$\begin{array}{c}\text { length } \\
\text { [m] }\end{array}$} & \multicolumn{2}{|c|}{ crown height } \\
\hline & & & & & & $\max$ \\
\hline $\mathbf{\Xi}$ & Wilhelmsburg & dike & 71 & 19,336 & 7.70 & 10.60 \\
\hline \multirow{7}{*}{ 离 } & & dune & 19 & 3,766 & 6.50 & 17.70 \\
\hline & Hörnum & dune/ tetrapods & 3 & 724 & 7.72 & 13.96 \\
\hline & & dune beach path & 14 & 412 & 8.12 & 16.06 \\
\hline & \multirow{4}{*}{ Westerland } & dune & 17 & 3,314 & 13.17 & 21.47 \\
\hline & & dune/ tetrapods & 9 & 1,411 & 12.96 & 20.97 \\
\hline & & dune beach path & 10 & 193 & 12.73 & 19.35 \\
\hline & & dike (incl. $2^{\text {nd }}$ dike line) & 32 & 13,808 & 3.82 & 7.44 \\
\hline
\end{tabular}

\section{RELIABILTY ANALYSIS}

\section{Methods}

Using a probabilistic approach by taking into account the uncertainties of input parameters and models, a reliability analysis of the flood defences was performed. For this purpose, different failure modes described by limit state equations $(\mathrm{z}=\mathrm{R}-\mathrm{S})$ were analysed. The flood defence line consists of a number of different types of flood defence structures. However, estuary/sea dikes, coastal dunes and flood defence walls/ sea walls were identified as the main linear flood defence elements in the pilot sites and the main focus was set on an analysis of these structures. For these defences, all failure mechanisms were examined based on the results of previous projects such as FLOODsite (Allsop et al., 2007) and ProDeich (Kortenhaus, 2003).

For different extreme storm surge scenarios determined by SP 1 (see Table 1) the conditional failure probabilities associated to all failure mechanisms were calculated using Monte-Carlo simulations. This procedure of calculating conditional failure probabilities for different extreme storm surge scenarios was chosen since it allowed for performing an event-based inundation modelling and damage estimation.

For each type of flood defence structure, failure mechanisms were organised in a fault tree. The structure of the fault tree represents the different chains of events leading to an overall failure of the flood defence structure (top event) which was defined in this study as flooding of the hinterland. The generic structure of the fault tree combining limit state equations for sea dikes and coastal dunes is shown in Figure 4. From the failure probability of each flood defence section, the overall failure probability of the flood defence system of each subarea was calculated also using a fault tree approach. For the failure probability calculations software tools such as ProDeich (Kortenhaus, 2003) were analysed, further developed and applied. 


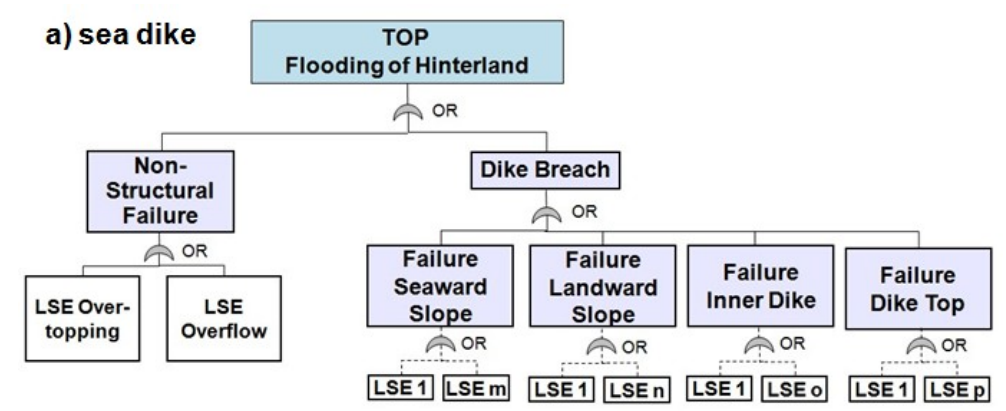

b) coastal dune

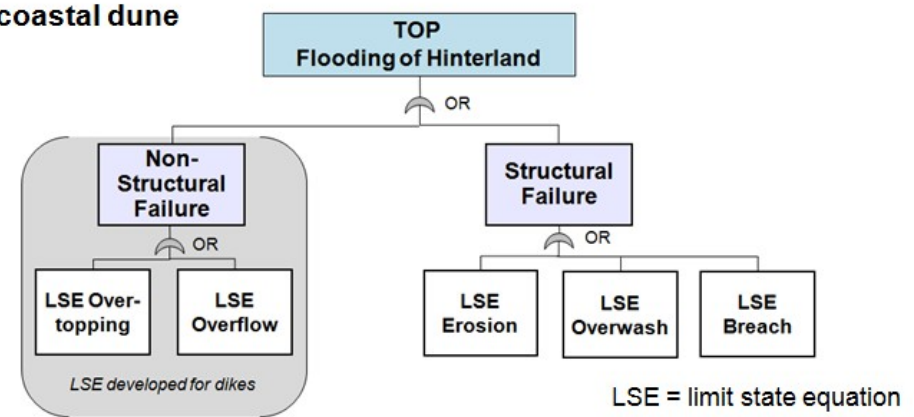

Figure 4. Generic fault tree combining limit state equations (LSE) of a) sea dikes and b) coastal dunes.

\section{Results}

For the reliability analysis of the linear flood defence elements a total of 35 failure mechanisms are considered in this study, i.e. 22 limit state equations for dikes, 5 limit state equations for coastal dunes and 8 limit state equations for flood defence walls. An overview of the applied limit state equations is given in Table 3. For further details it is referred to Kortenhaus (2003), Allsop et al. (2007) and Naulin et al. (2011). The overall results of the failure probabilities of the top event, i.e. flooding of the hinterland, reach very high values of up to $P_{f}=1.0$ for the investigated extreme storm surge scenarios. The dominating failure mechanisms leading to the high probability of flooding are identified as nonstructural failure in terms of wave overtopping and overflow due to the very high storm surge level as compared to the dike heights (water level higher than the crest height). Hence, the overall conditional failure probability $\mathrm{P}_{\mathrm{f} \text {,cond }}$ depends on the exceedance probability $\mathrm{P}_{\mathrm{e}}$ of the very extreme storm surge scenarios (see Table 1), e.g. for the storm surge scenario HH-XR2010A the overall conditional failure probability $\mathrm{P}_{\mathrm{f} \text {,cond }}$ is determined to $7.72 \cdot 10^{-6}$ per year.

However, an important task is to further analyse the structural stability of the flood defences. A dike breach may lead to extreme discharges and very high velocities of the flood wave propagation and hence a breach represents severe consequences for the hinterland. In order to analyse the structural stability of dikes, the results of the failure probabilities resulting from LSEs leading to a dike breach were examined. In the following, the results are exemplarily shown for the storm surge scenario $\mathrm{HH}$ XR2010A for the dike sections of Wilhelmsburg, Hamburg.

Figure 5a shows the failure probabilities of the inner slope for all dike sections. For most dikes the probabilities of failure of the inner dike slope are rather low $\left(\mathrm{P}_{\mathrm{f}}=1.0 \cdot 10^{-4}\right)$. Only in some areas higher values (between $1.0 \cdot 10^{-2}$ and $1.0 \cdot 10^{-3}$ ) were calculated. These dike sections were then identified as weak spots since they had less resistant inner slopes or were exposed to more severe hydraulic loading. Breach modelling has been applied to these “weaker” sections as described in the next subsection. 
Table. 3. Overview of considered limit state equations in this study.

\begin{tabular}{|c|c|c|}
\hline \multirow{28}{*}{ 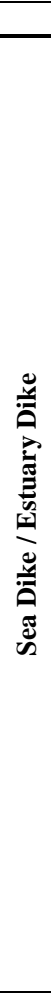 } & No. & LSE Name \\
\hline & \multicolumn{2}{|c|}{ Non-Structural Failure of Dikes } \\
\hline & 1 & overflow (functional failure) \\
\hline & 2 & wave overtopping (functional failure) \\
\hline & \multicolumn{2}{|c|}{ Failure of Seaward Slope of Dikes } \\
\hline & 3 & velocity wave run-up \\
\hline & 4 & wave driven erosion \\
\hline & 5 & wave impact \\
\hline & 6 & cliff erosion by wave impact \\
\hline & 7 & erosion of revetment armour (rock) \\
\hline & 8 & uplift of the revetment \\
\hline & 9 & deep slip (Bishop) \\
\hline & \multicolumn{2}{|c|}{ Failure of Landward Slope of Dikes } \\
\hline & 10 & overflow velocity \\
\hline & 11 & wave overtopping velocity \\
\hline & 12 & erosion by overflow/ wave overtopping \\
\hline & 13 & sliding of clay layer* \\
\hline & 14 & clay uplift* \\
\hline & 15 & deep slip (Bishop) \\
\hline & 16 & partial breach \\
\hline & \multicolumn{2}{|c|}{ Sliding and Internal Erosion of Dikes } \\
\hline & 17 & sliding of dike with clay cover (functional failure) \\
\hline & 18 & piping* \\
\hline & 19 & matrix erosion* \\
\hline & \multicolumn{2}{|c|}{ Failure of Dike Top } \\
\hline & 20 & erosion of inner slope \& dike top failure* \\
\hline & 21 & sliding of inner slope \& dike top failure* \\
\hline & 22 & clay uplift of inner slope \& dike top failure* \\
\hline \multirow{8}{*}{ 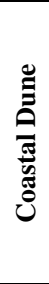 } & \multicolumn{2}{|c|}{ Non-Structural Failure of Coastal Dunes } \\
\hline & 1 & overflow (functional failure) \\
\hline & 2 & wave overtopping (functional failure) \\
\hline & \multicolumn{2}{|c|}{ Failure of Seaward Slope of Coastal Dunes } \\
\hline & 3 & erosion \\
\hline & \multicolumn{2}{|c|}{ Failure of Landward Slope of Coastal Dunes } \\
\hline & 4 & overwash \\
\hline & 5 & breaching \\
\hline
\end{tabular}

Furthermore, the stability of the coastal dunes at Sylt Island was analysed. In the following the results of the failure probabilities of the coastal dunes of the west side of Hörnum are exemplarily given for the storm surge scenario SY-XR2010A. Erosion of the dunes was determined to be the dominating failure mechanism. For the limit state equation of erosion failure probabilities up to $\mathrm{P}_{\mathrm{f}}=$ $4.2 \cdot 10^{-2}$ were calculated. The results of all 35 dune sections are summarized in Figure 5.

The results of the probability of flooding were delivered to SP 4 for risk integration (Burzel et al. 2012, Dassanayake et al. 2012). Moreover, the fault tree analysis allowed determining the probability of breaching of dunes and dikes and gave an indication of the causes of breach initiation, e.g. wave impact on seaward slope or overtopping on landward slope. 
a) Wilhelmsburg, Hamburg

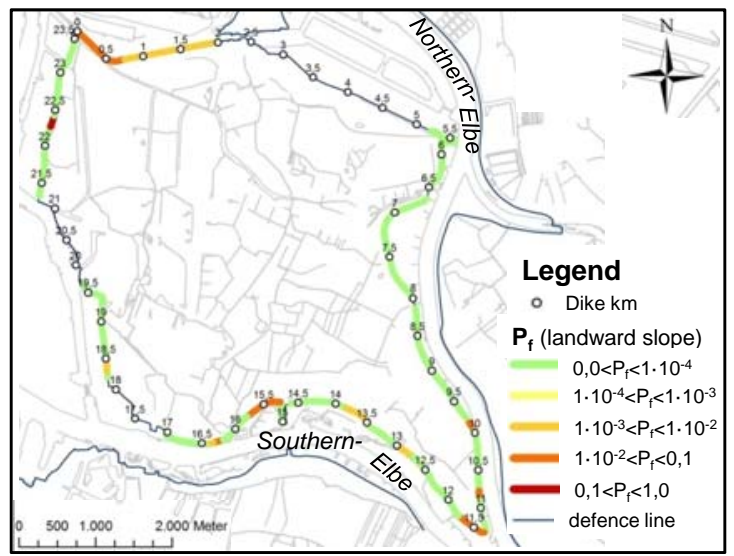

b) Hörum, Sylt

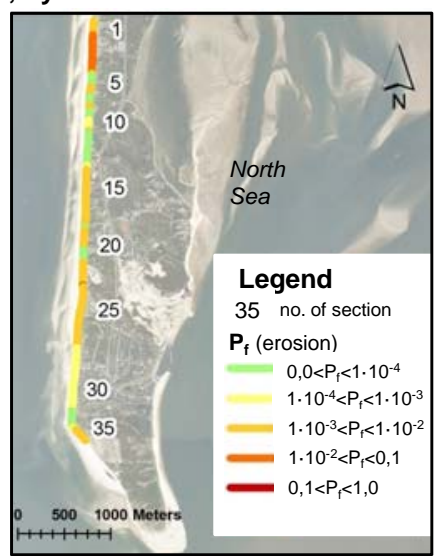

Figure 5. Results of the study areas: a) Failure probabilities of dike breach initiated from a failure of the landward slope for dike sections in Wilhelmsburg, Hamburg; b) Failure probabilities of erosion of coastal dunes in Hörnum, Sylt.

\section{WAVE OVERTOPPINGI OVERFLOW AND BREACHING OF DIKES}

\section{Methods}

The boundary conditions for the inundation simulations of the hinterland were determined by wave overtopping and/or overflow calculations as well as dike breach modelling. For this purpose, the unsteady conditions of water level and wave parameters at the toe of the defences were considered as input data using time series of about 28 hours with time steps of 15 minutes provided by SP 1/SP 3. As simplification for the harbour of Hamburg the influence of some polder areas were neglected. The polders actually represent storage capacities (although they are not designed for flood control).

The combined overtopping and overflow discharges were calculated according to two approaches (i) for specific cross sections of dikes a numerical model developed by Tuan and Oumeraci (2010) was applied; (ii) for all sections of the flood defence line, i.e. sloped structures and vertical structures, the discharges were calculated using existing weir formulae and wave overtopping formulae after Bleck et al. (2000) and EurOtop (2007).

\section{Results}

The results of the modelling of wave overtopping and/or overflow are presented using the example of Wilhelmsburg, Hamburg, and Westerland, Sylt. The discharge rates were determined for all identified sections of the flood defence line. The results of the maximum wave overtopping/overflow rate $\mathrm{q}_{\max }[\mathrm{l} /(\mathrm{sm})]$ and total volume $\mathrm{V}\left[\mathrm{m}^{3}\right]$ for different storm surge scenarios are shown in Table 4 for Wilhelmsburg and in Table 5 for Westerland, respectively.

For Wilhelmsburg some polder areas were neglected for the numerical modelling of the water level and wave parameters in front of the dike (Ujeyl 2012). This is assumed to reduce the loading of the flood defence structure in Wilhelmsburg so that the overtopping rates of the north-eastern parts of the flood defence sections was likely to be overestimated with maximum discharges calculated at a section of the flood defence wall. Keeping this in mind, for Wilhelmsburg, extreme discharges with total volumes of 7.2 million $\mathrm{m}^{3}$ and 120 million $\mathrm{m}^{3}$ (for the whole subarea) for the analysed storm surge scenarios HH-XR2010A and HH-XR2010C were calculated, respectively.

For the storm surge scenarios HH-XR2010A-90 and HH-XR2010B (see Table 1) volumes of $700 \mathrm{~m}^{3}$ and 7,300 $\mathrm{m}^{3}$ were determined. The time period of wave overtopping/ overflow varies from 4.25 to 12.0 hours. Hence, not only the extreme peaks of the storm surge water level had an influence on the overtopping volumes but also the intensity or fullness of the storm surge curves.

For Westerland rather small overtopping rates of less than $0.5 \mathrm{l} /(\mathrm{sm})$ could be modelled for current storm surge scenarios (“2010”). For future storm surge scenarios (“2100”) considering an increase of $80 \mathrm{~cm}$ in sea level rise total volumes of $14,000 \mathrm{~m}^{3}$ (SY-XR2100A80) to 25,000 $\mathrm{m}^{3}$ (SY-XR2100C80) could be estimated. 
Table. 4. Results of maximum wave overtopping/overflow rate $q_{\max }[l /(\mathrm{sm})]$ and total volume $\mathrm{V}\left[\mathrm{m}^{3}\right]$ for different storm surge scenarios at Wilhelmsburg, Hamburg.

\begin{tabular}{|c|c|c|}
\hline storm surge [scenario] & $\mathbf{q} \max \left[\mathbf{l} /\left(\mathbf{s}^{*} \mathbf{m}\right)\right]$ & $\mathbf{V}$ total $\left[\mathbf{m}^{3}\right]$ \\
\hline HH_XR2010A & $660^{*}$ & $\sim 7.2$ Mio. \\
\hline HH_XR2010B & $2^{*}$ & $\sim 7,300$ \\
\hline HH_XR2010C & $2,260^{*}$ & $>120$ million \\
\hline HH_XR2010A-90 & $0.5^{*}$ & $\sim 700$ \\
\hline
\end{tabular}

*maximum overtopping rates at a section of a flood defence wall

Table. 5. Results of maximum wave overtopping/overflow rate $q_{\max }[l /(\mathrm{sm})]$ and total volume $V$ [m $\left.{ }^{3}\right]$ for different storm surge scenarios at Westerland Sylt.

\begin{tabular}{|c|c|c|c|c|}
\hline storm surge & Westerland West & $\begin{array}{c}\text { Rantumdamm } \\
\text { (1st dike line; } \\
\text { 2nd dike line } \mathrm{q}=0 \text { ) }\end{array}$ & Nössedeich & total \\
\hline [scenario] & $\mathrm{q} \max \left[\mathbf{l} /\left(\mathrm{s}^{*} \mathrm{~m}\right)\right]$ & q $\max \left[\mathbf{l} /\left(\mathbf{s}^{*} \mathbf{m}\right)\right]$ & q $\max \left[l /\left(\mathbf{s}^{*} \mathrm{~m}\right)\right]$ & V total $\left[m^{3}\right]$ \\
\hline SY-XR2010A & 1 & 730 & $<0.5$ & $\sim 2,000$ \\
\hline SY-XR2010B & $<0.5$ & 90 & $<0.5$ & $\sim 300$ \\
\hline SY-XR2010C & $<0.5$ & 600 & $<0.5$ & $\sim 800$ \\
\hline SY-XR2010A-95 & $<0.5$ & 10 & $<0.5$ & $\sim 0$ \\
\hline SY-XR2100A80 & 7 & 2,960 & 13 & $\sim 25,000$ \\
\hline SY-XR2100C80 & 3 & 2,760 & 8 & $\sim 14,000$ \\
\hline
\end{tabular}

\section{BREACHING OF DIKES AND EROSION OF COASTAL DUNES}

\section{Methods}

The breach modelling was performed for specific cross sections of dikes. The results of the reliability analysis (see previous subsection) indicated if and where breaching might occur, i.e. segments with high probabilities of LSEs leading to dike breaching.

For the different causes of breach initiation, there are different breaching models available, e.g. breaching initiated on the landside by wave overtopping and overflow is described by D'Eliso et al. (2006) and Tuan and Oumeraci $(2010,2011)$ as well as breaching initiated on the seaside by breaking wave impacts is described by Stanczak \& Oumeraci (2012). Depending on the loading conditions (wave overtopping/ overflow or breaking wave impacts) and thus depending on the breach initiation (landside or seaside) one of the above introduced breaching models was applied to the case study area.

Furthermore, for coastal dunes the model UNIBEST-DE by Deltares (Steezel, 1993) is applied in order to simulate erosion of coastal dunes.

\section{Results}

The results of the reliability analysis illustrated that overflow and wave overtopping represented the major forcing of the analysed storm surge scenarios. For this reason wave overtopping-induced erosion of the inner slope of grassed sea-dikes was simulated, e.g. for the storm surge scenario $\mathrm{HH}$ XR2010A in Hamburg Wilhelmsburg. The breach initiation was modelled using the BREID model which is a numerical model for simulating BREaching of Inhomogeneous sea Dikes (BREID) developed by Tuan and Oumeraci (2010, 2012).

For this purpose, the effects of different grass conditions were analysed. Therefore, laboratory experiences analysing the root volume ratio of grass samples in Hamburg Wilhelmsburg were performed (Kaste, 2011). Good grass conditions were determined and the results were implemented in the model. The modelling of breach initiation was exemplarily performed for one critical section. The analysis - which is described in detail in Naulin et al. (2010) - revealed that even for moderate grass conditions, the erosion of the grass layer was initiated to a depth of only $7.0 \mathrm{~cm}$; i.e. a full breach would not develop.

However, in order to determine a dike breach scenario the effects of poor grass conditions were assumed and the full breach development was estimated applying the model of D'Eliso et al. (2006). 
An overview of the results of the breach modelling due to wave overtopping and overflow for different storm surge scenarios is given in Table 6.

Table. 6. Overview of the results of breach modelling due to wave overtopping/overflow for different storm surge scenarios.

\begin{tabular}{|c|c|c|c|}
\hline dike section & storm surge scenario & $\begin{array}{c}\text { breach initiation } \\
\text { (erosion of grass and clay layer) }\end{array}$ & full breach \\
\hline \multirow{6}{*}{$\begin{array}{l}\text { Klütjenfelder } \\
\text { Hauptdeich } \\
\text { (crown height } \\
\text { 7,80 mNN; } \\
\text { slope 1:3) }\end{array}$} & HH_XR2010A & $\mathrm{X}$ & $\mathrm{X}^{*}$ \\
\hline & HH_XR2010B & - & - \\
\hline & HH_XR2010C & $\mathrm{X}$ & $\mathrm{X}$ \\
\hline & HH_XR2010A-90 & - & - \\
\hline & HH_XR2100A80 & $\mathrm{X}$ & $\mathrm{X}$ \\
\hline & HH_XR2100C80 & $\mathrm{X}$ & $\mathrm{X}$ \\
\hline \multirow{6}{*}{$\begin{array}{l}\text { Rantumdamm } \\
\text { (1st dike line, } \\
\text { crown height } \\
\text { 4,64 mNN; } \\
\text { slope 1:4) }\end{array}$} & SY_XR2010A & $\mathrm{X}$ & - \\
\hline & SY_XR2010B & - & - \\
\hline & SY_XR2010C & $\mathrm{X}$ & - \\
\hline & SY_XR2010A-95 & - & - \\
\hline & SY_XR2100A80 & $\mathrm{X}$ & $\mathrm{X}$ \\
\hline & SY_XR2100C80 & $\mathrm{X}$ & $\mathrm{X}$ \\
\hline \multirow{2}{*}{$\begin{array}{c}\text { Rantum } \\
\text { Binnendeich } \\
\text { (2nd dike line } \\
\text { crown height } \\
\text { 3,94 mNN; } \\
\text { slope 1:2,5) }\end{array}$} & SY_XR2100A80 & $\mathrm{X}^{* *}$ & $\mathrm{X}^{* *}$ \\
\hline & SY_XR2100C80 & $\mathrm{X}^{* *}$ & $\mathrm{X}^{* *}$ \\
\hline
\end{tabular}

Assumption: * poor grass conditions; ** total breach of first dike line

Examples of the results of the dike breach modelling applying the model of D'Eliso et al. (2006) are shown in Table 7. For Hamburg under the assumption of poor grass conditions a very extreme dike breach could develop for the storm surge HH-XR2010A. The final breach width of ca. $420 \mathrm{~m}$ and the breach outflow hydrograph with a total volume of approximately 72 million $\mathrm{m}^{3}$ were obtained in order to specify the initial conditions of the flood wave at the breach for inundation modelling of the hinterland. For Sylt a dike breach with a breach width of $18 \mathrm{~m}$ and a total volume of 4 million $\mathrm{m}^{3}$ were exemplarily determined.

A detailed analysis of the inundation modelling and damage estimation of the hinterland has been carried out by SP 3 (Ujeyl et al. 2012) using the time series of the discharges of the flood defence sections as input parameters.

Table. 7. Examples of results of dike breach modelling applying the breach model of D'Eliso et al. (2006).

\begin{tabular}{|c|c|c|c|c|}
\hline storm surge & dike section & breach width & volume & assumption \\
\hline [scenario] & [name] & [m] & {$\left[\mathbf{m}^{3}\right]$} & {$[-]$} \\
\hline HH-XR2010A & $\begin{array}{l}\text { Klütjenfelder } \\
\text { Hauptdeich } \\
\text { (crown height } \\
\text { 7,80 mNN; } \\
\text { slope 1:3) }\end{array}$ & $\sim 400$ & $\sim 72$ million & poor grass condition \\
\hline SY-XR2100A80 & $\begin{array}{c}\text { Rantum } \\
\text { Binnendeich } \\
\text { (2nd dike line } \\
\text { crown height } \\
\text { 3,94 mNN; } \\
\text { slope 1:2,5) }\end{array}$ & $\sim 18$ & $\sim 4$ million & dike breach of $1^{\text {st }}$ dike line \\
\hline
\end{tabular}

For coastal dunes at Sylt the results of the reliability analysis illustrated that erosion represented the major forcing of the analysed storm surge scenarios. Due to the large crown heights (12.3 $\mathrm{mNN}$ to $21.5 \mathrm{mNN})$ and width (100 $\mathrm{m}$ to $500 \mathrm{~m})$ of the dunes, the probability of overwash or a total breach is very low $\left(\mathrm{P}_{\mathrm{f}}<1 \cdot 10^{-6}\right)$. Therefore, the process of erosion was simulated by the model UNIBEST-DE. In general for the different current storm surge scenarios severe erosion volumes of $57 \mathrm{~m}^{3} / \mathrm{m}$ above still water level and retreats of $25 \mathrm{~m}$ at an elevation at $4.5 \mathrm{mNN}$ could be modelled, e.g. for the storm surge 
scenario SY-XR2010C (Figure 6). However, a full breach could not be simulated for the analysed dune profiles.

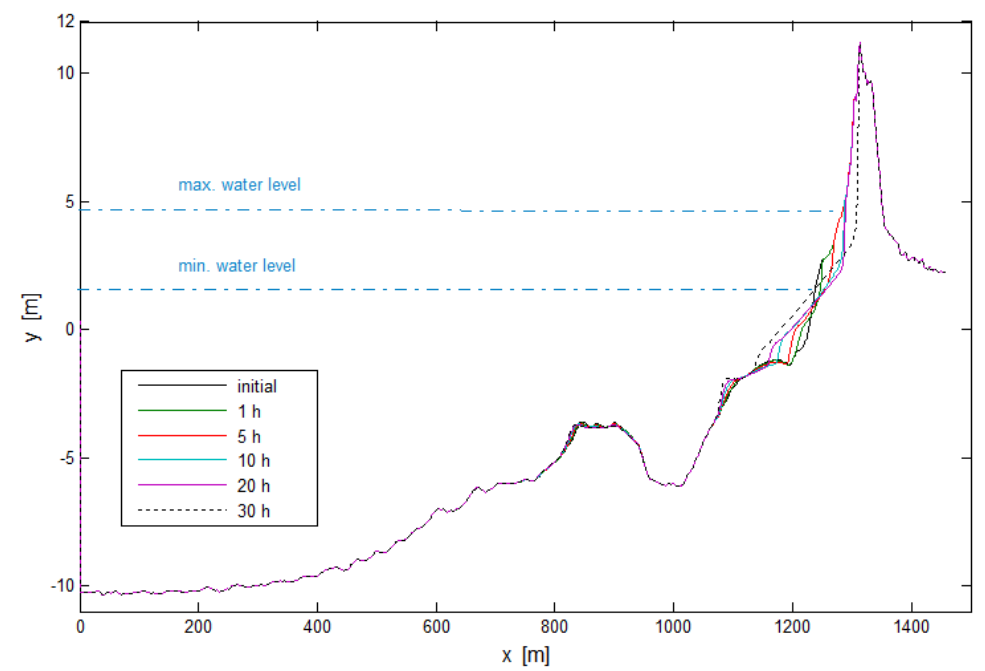

Figure 6. Initial and erosion profile for one cross section of a coastal dune in Hörnum, Sylt for the storm surge scenario SY-XR2010C.

\section{TIME-DEPENDENT ASPECTS IN RELIABILTY ANALYSIS}

Generally, failure mechanisms of flood defences are time-dependent processes. This aspect has been discussed in Naulin et al. (2011) for short term time scales as a function of the storm surge parameters and is briefly summarized in this section.

The resistance and the loading of the structure vary over time and according to different time scales three general categories can be distinguished (a) short term, e.g. impacts of storm surges such as wave impacts and wave overtopping, (b) mid term: seasonal changes, or (c) long term: mean sea level rise, degradation effects.

In general, both resistance and loading terms of the limit state equations would actually require time-dependent reliability analysis. However, until now in reliability analysis most methods consider only time-independent values including a distribution function for the uncertainties of the parameters of the limit state equations.

Methods for time-dependent reliability analysis of flood defences have been addressed by Buijs et al. (2009). Furthermore, improvements for taking into account short term time-dependent effects as the storm surge curve have been made for the determination of the exceedance probability of the storm surges by applying multivariate statistics as proposed by Wahl et al. (2010). Hence, not only the peak water level but also the "fullness", i.e. the intensity, of the storm surge curve is considered.

In Naulin et al. $(2011,2012)$ an approach was introduced to consider the unsteady conditions of storm surges which are implemented exemplarily for the failure mechanisms of 'wave overtopping' and 'overflow'. The limit state equations were adapted from comparing discharges q to time-dependent volumes $\mathrm{V}(\mathrm{t})$. The volumes are determined using existing weir formulae and wave overtopping formulae for all sections of the flood defence line as previously described in this paper.

The consideration of time-dependent calculation of volumes instead of discharges with constant parameters has considerable advantages as it represents a better approximation of the time-dependent process, i.e. detailed estimation of overtopping volume. Furthermore, the storage capacity of the hinterland is taken into account, i.e. exceedance of critical overtopping discharge might occur for a short period at the peak of the storm surge, but does not necessarily lead to severe flooding.

\section{SUMMARY AND CONCLUSIONS}

The German research project XtremRisK (www.xtremrsik.de) has developed methods for an integrated flood risk analysis for extreme storm surges and consists of four subprojects. The city of Hamburg serves as a pilot site for an estuarine urban area, and the island of Sylt as a pilot site for an open coast. Subproject 2 of XtremRisK has dealt with a reliability analysis and breach modelling of coastal and estuarine flood defences. 
In this paper, the methods and the results of reliability analyses in order to determine failure probabilities of flood defences as well as the methods and the results for modelling of wave overtopping and breaching of sea dikes are outlined.

Within the reliability analysis software tools were developed for the identified main linear flood defence elements of the pilot sites, i.e. estuary/sea dikes; coastal dunes and flood defence walls/ sea walls. Therefore, 35 limit sate equations were considered and up to over 80 input parameters were determined for characteristic cross sections of the flood defences.

In order to determine discharges as initial conditions of the flood wave propagation into the hinterland wave overtopping/overflow calculations were performed and existing dike breach models have been used.

These methods were applied to the pilot sites of Hamburg and Sylt Island where the failure probabilities were determined as conditional probabilities by an event-based procedure whereas the exceedance probabilities of water levels were determined separately by multivariate statistics. Since very extreme storm surge scenarios with low exceedance probabilities and very high water levels and intensities were analysed (see Table 1), very high failure probabilities for wave overtopping and overflow of up to $\mathrm{P}_{\mathrm{f}}=1.0$ were determined (assuming a critical wave overtopping/overflow ratio of $\left.\mathrm{q}_{\text {crit }}=0.5 \mathrm{l} /(\mathrm{sm})\right)$.

Taking into account the exceedance proability (see Table 1), in Hamburg storm surge scenarios with conditional failure probabilities between $\mathrm{P}_{\mathrm{f} \text {, cond }}=2.4 \cdot 10^{-3}$ per year and $\mathrm{P}_{\mathrm{f} \text {,cond }}=5.3 \cdot 10^{-8}$ per year were analyzed. Calculations of wave overtopping/ overflow have shown that minor or moderate overtopping rates with $0.5 \mathrm{l} /(\mathrm{sm})$ to $2.0 \mathrm{l} /(\mathrm{sm})$ and volumes of $700 \mathrm{~m}^{3}$ and 7,300 $\mathrm{m}^{3}$ were determined for the storm surge scenarios HH-XR2010A-90 and HH-XR2010B (see Table 1). Severe flooding with total volumes of 7.2 million $\mathrm{m}^{3}$ and 120 million $\mathrm{m}^{3}$ will occur for the analysed storm surge scenarios HH-XR2010A and HH-XR2010C.

However, for the same storm surge scenarios, e.g. HH-XR2010A, the failure probability of full dike breach seems to be rather low $\left(\mathrm{P}_{\mathrm{f}}=1.0 \cdot 10^{-4}\right)$. Sections with higher probabilities $\left(\mathrm{P}_{\mathrm{f}}=1.0 \cdot 10^{-2}-\right.$ $1.0 \cdot 10^{-3}$ ) were identified as potential weak points.

The results of the breach modelling pointed out that a breach initiation could not be modelled for the storm surge scenarios HH-XR2010A-90 and HH-XR2010B. For the scenario HH-XR2010A a breach could be initiated at the landward side but would only fully develop under the assumption of poor grass conditions. Under these conditions a very extreme dike breach scenario was estimated with a breach width of $400 \mathrm{~m}$ and a volume of 72 million $\mathrm{m}^{3}$.

Taking into account the exceedance proability (see Table 1), at Sylt storm surge scenarios with conditional failure probabilities between $\mathrm{P}_{\mathrm{f} \text {, cond }}=3,06 \cdot 10^{-4}$ per year and $\mathrm{P}_{\mathrm{f} \text {, cond }}=5,38 \cdot 10^{-6}$ per year were analyzed for Hörnum and Westerland. For Westerland (in the west of the island) rather small overtopping rates of less than $0.5 \mathrm{l} /(\mathrm{sm})$ were modelled for current storm surge scenarios ("2010”). However, for the first dike line of the Rantumdamm (east of the island) $10 \mathrm{l} /(\mathrm{sm})$ to $730 \mathrm{l} /(\mathrm{sm})$ were calculated for current scenarios but the second dike line ("Rantum Binnendeich") serves as a protection of the hinterland. A breach initiation of the first dike line was simulated for the scenarios SY-XR2010A and SY-XR2010C. However, the storage capacity of the Rantumbecken is sufficient so that no flooding will occur from the east side of the island.

For future storm surge scenarios ("2100") considering an increase of $80 \mathrm{~cm}$ in sea level rise total volumes of $14,000 \mathrm{~m}^{3}$ (SY-XR2100A80) to 25,000 $\mathrm{m}^{3}$ (SY-XR2100C80) were estimated and a full breach could be modelled for the Rantumdamm. Under the assumption of a toal dike breach of the first dike line a dike breach of the second dike line with a breach width of $18 \mathrm{~m}$ and a total volume of 4 million $\mathrm{m}^{3}$ were exemplarily determined.

Furthermore, the process of erosion was simulated by the model UNIBEST-DE. In general for the different current storm surge scenarios severe erosion volumes of $57 \mathrm{~m} / \mathrm{m}$ above still water level and retreats of $25 \mathrm{~m}$ at an elevation at $4.5 \mathrm{mNN}$ could be modelled, e.g. for the storm surge scenario SYXR2010C. However, a full breach could not be simulated for the analysed dune profiles.

The overall results of flooding probabilities and initial flooding conditions are required input data to Subproject 3 in order to model the inundation of the hinterland for damage estimation and to Subproject 4 in order to combine the results in an integrated risk analysis.

Moreover, methods are analysed in order to consider the time dependence of failure mechanisms in terms of the unsteady conditions of the storm surge, e.g. by changing the limit state equations for 'wave overtopping' and 'overflow' from discharges to volumes as outlined in this paper.

Although improvements within the risk pathways analyses could be made, there are remaining simplifications and research gaps which need to be further investigated. For example as one 
simplification the length effects, increasing probability with increasing length of the analysed section, were not considered in this study.

In addition, future challenges include, e.g. a systematic analysis of "point structures" where human and organisational errors may contribute to higher failure probabilities. In addition, weak points with potential increase of failure probabilities such as transitions between different types of flood defence elements or damages due to borrowing animals have to be further investigated.

\section{ACKNOWLEDGMENTS}

The project XtremRisK (www.xtremrisk.de) is funded by the German Federal Ministry of Education and Research BMBF (Project No. 03 F 0483 A). This funding is gratefully acknowledged.

Furthermore, we thank our project partners (i.e. colleagues from the Universities of Siegen and Hamburg-Harburg and from the Agency of Roads, Bridges and Waters in Hamburg) for a pleasant and trustful cooperation.

Last but not least, the collaboration and the provision of data as well as expert's discussions by the Cooperative and Consulting Partners of the project such as Schleswig-Holstein's Government-Owned Company for Coastal Protection, National Parks and Ocean Protection (LKN-SH), Hamburg Port Authority (HPA) and Agency of Roads, Bridges and Waters Hamburg (LSBG) are also gratefully acknowledged.

\section{REFERENCES}

Allsop, N.W.H.; Buijs, F.; Morris, M.W.; Hassan, R.; Young, M.J.; Doorn, N.; Van der Meer, J.W.; Kortenhaus, A.; Van Gelder, P.H.A.J.M.; Dyer, M.; Redaelli, M.; Visser, P.J.; Bettess, R.; Lesniewska, D. (2007): Failure mechanisms for flood defence structures. FLOODsite - Integrated Flood Risk Assessment and Management Methodologies, T04-05-01, 150 p.

Bleck, M.; Oumeraci, H.; Schüttrumpf, H. (2000): Combined wave overtopping and overflow of dikes and seawalls. Proceedings International Conference Coastal Engineering, ASCE, no. 27, Poster paper, Sydney, Australia.

Buijs, F.A.;Hall, J.W.;Sayers, P.B.; Van Gelder, P.H.A.J.M. (2009): Time-dependent reliability analysis of flood de-fences. Elsevier, Reliability Engineering \& System Safety, 94, pp. 1942-1953.

Burzel, A. , Dassanayake D.R.\& Oumeraci, H. (2012): Spatial Modelling of tangible and intangible Losses in Integrated Risk Analysis - Results of the XtremRisK Proc, 2nd European Conf. on FLOODrisk Management, Rotterdam

Dassanayake, D.R., Burzel, A. \& Oumeraci, H. (2012). Intangible Flood Losses: Methodologies for their Evaluation and Integration in Flood Risk Analysis. Proc, 2nd European Conf. on FLOODrisk Management, Rotterdam.

D'Eliso, C.; Oumeraci, H.; Kortenhaus, A. (2006): Breaching of coastal dikes induced by wave overtopping. Proc. 30th International Conference Coastal Engineering (ICCE), San Diego, USA, ASCE, vol. 3, pp. 2844-2856.

EurOtop (2007): European Overtopping Manual. Pullen, T.; Allsop, N.W.H.; Bruce, T.; Kortenhaus, A.; Schüttrumpf, H.; Van der Meer, J.W.; Kuratorium für Forschung im Küsteningenieurwesen: Die Küste, Heft 73, www.overtopping-manual.com.

Gönnert, G., Thumm, S. \& Gerkensmeier, B. (2012). Empirical analyses of extreme storm surges Results of the Xtrem-RisK project. Proc, 2nd European Conf. on FLOODrisk Management, Rotterdam

Holthuijsen, L.H., Booij, N. and T.H.C. Herbers, 1989: A prediction model for stationary, short-crested waves in shallow water with ambient currents, Coastal Engineering, 13, 23-54

IPCC 2007. Climate change 2007: WG II: Impacts, Adaptation and Vulnerability, Chapter 6. Coastal systems and low lying areas. Intergovernmental Panel on Climate Change (IPCC), Cambridge.

Kaste, D. (2011): Untersuchung der Grasqualität und Modellierung der Graserosion von Deichen bei Wellenüberlauf am Beispiel von Hamburg Wilhelmsburg. TU Braunschweig, Studienarbeit, (Student Project Work), Leichtweiß-Institute, Germany, 50 p. (unpublished).

Kortenhaus, A. (2003): Probabilistische Methoden für Nord-seedeiche. Ph.D. thesis, Dissertation, Fachbereich Bauingenieurwesen, Leichtweiß-Institut für Wasserbau, Technische Universität Braunschweig (2003), Braunschweig, Germany, 154 p.

Naulin, M.; Kortenhaus, A.; Oumeraci, H. (2010): Failure probability of flood defence structures/systems in risk analysis for extreme storm surges. 32nd International Conference on Coastal Engineering (ICCE 2010), ASCE, Shanghai, China, 15 p. 
Naulin, M.; Kortenhaus, A.; Oumeraci, H. (2011): Reliability Analysis and Breach Modelling of Coastal and Estuarine Flood Defences. Proceedings 3rd International Symposium on Geotechnical Safety and Risk (ISGSR 2011), Munich, Germany, pp. 577-586.

Naulin, M.; Hinze, K.; Kortenhaus, A.; Oumeraci, H. (2012): Reliability Analysis of Grass-Covered Sea and Estuary Dikes Focusing on Time-Dependent Failure Mechanisms - State-of-the-ArtReport, Leichtweiß-Institute (in preparation).

Oumeraci, H.; Burzel, A.; Dassanayake, D.; Gönnert, G.; Jen-sen, J.; Kortenhaus, A.; Mudersbach, C.; Naulin, M.; Pasche, E.; Sossidi, K.; Thumm, S.; Ujeyl, G.; Wahl, T. (2012): Integrated Flood Risk Analysis for Extreme Storm Surges at Open Coasts and in Estuaries: Background, Methodology, Key Results and Lessons Learned - Results of the XtremRisK Project Proc, 2nd European Conf. on FLOODrisk Management, Rotterdam

Roelvink et al. (2010): XBeach Model Description and Manual, Unesco-IHE, Deltares and Delft University

Stanczak, G.; Oumeraci, H. (2012): Modeling sea dike breaching induced by breaking wave impactlaboratory experi-ments and computational model. Coastal Engineering, Vol 59, Nr. 1, pp 28-37

Steetzel, H.J. (1993): Cross-shore transport during storm surges. Ph.D. thesis, Den Haag, The Netherlands, 242 p., 1 Appendix.

Tuan, T.Q.; Oumeraci, H. (2010): A numerical model of wave overtopping on seadikes. Coastal Engineering, vol. 57, pp. 757-772.

Tuan, T.Q.; Oumeraci, H. (2012): Modelling of wave overtopping-induced erosion of grassed inner sea-dike slopes. Springer: Natural Hazards, Vol. 61 (published 30 March 2012 online first).

Ujeyl. G., Fröhle, P. \& Pasche, E. 2012b. Evaluating direct damages of residential and commercial assets on a micro scale - Results of the XtremRisK Project. Proc, 2nd European Conf. on FLOODrisk Management, Rotterdam.

Van Gelder, P.H.A.J.M.; Buijs, F.; Van, C.M.; ter Horst, W.L.A.; Kanning, W.; Nejad, M.; Gupta, S.; Shams, R.; Van Erp, N.; Gouldby, B.; Kingston, G.; Sayers, P.B.; Wills, M.; Kortenhaus, A.; Lambrecht, H.-J. (2008): Reliability analysis of flood sea defence structures and systems. FLOODsite Executive Summary T07-09-20, 21 p.

Wahl, T.; Jensen, J.; Mudersbach, C. (2010): A Multivariate Statistical Model for Advanced Storm Surge Analyses in the North Sea, Proc. 32nd International Conference Coastal Engineering (ICCE), Shanghai, China.

Wahl, T., C. Mudersbach, C.; Jensen,J. (2011): Assessing the hydrodynamic boundary conditions for risk analyses in coastal areas: a stochastic storm surge model, Nat. Hazards Earth Syst. Sci., 11, 2925-2939, doi:10.5194/nhess-11-2925-2011, 2011.

Wahl, T., Mudersbach, C. \& Jensen, J. (2012). Statistical assessment of storm surge scenarios within integrated risk analyses - Results of the XtremRisK project. Proc, 2nd European Conf. on FLOODrisk Management, Rotterdam 